\title{
John Cage, Gilles Deleuze, and the Idea of Sound
}

\section{Iain Campbell}

[draft only, final version published in parallax, 23:3, 361-378,

DOI:10.1080/13534645.2017.1343785]

Across John Cage's writings there is one moment to which he would often return, posing it as a turning point, a kind of singular epiphany in his thought and work. This is his famous visit to an anechoic chamber, and the consequent 'discovery' of his concept of silence. Describing his visit to the chamber, an environment designed to have as little acoustic resonance as possible and as such to be as silent as possible, Cage recounts hearing two sounds, one low and one high. Asking the engineer what these sounds were, Cage was told that the former was the sound of his blood in circulation, the latter his nervous system in operation. What Cage takes from this is that there can be no genuine silence, that 'until I die there will be sounds'. This in turn entails a conception of sound wherein it is not defined simply by its analytical characteristics, but also by how it necessarily exceeds intentionality, of both composer and of listener.

This is the basis for Cage's often-repeated but obscure claim that the function of art is to 'imitate Nature in her manner of operation', ${ }^{2}$ and by extension the other oft-repeated Cagean mantra of 'let[ting] sounds be themselves' ${ }^{3}$ - two cornerstones of an understanding of art in which the certainty of a creative or observational standpoint cannot serve as its foundation. However, what this 'imitation' involves, what it means to speak of a 'manner of operation' or indeed of 'Nature', and what this 'letting be' could consist in, is a complex matter which takes different shapes across Cage's career. Throughout, however, we find a constant engagement and re-engagement with the idea of sound - at some points seeming to maintain consistency and unity, at others mutating and drawing relations in unexpected ways.

In this essay we will take this outline of Cage's understanding of sound as the starting point for an evaluation of that term in the field of sound studies. Drawing together two of the most influential figures in the field, we will take Cage's thought and work as a lens through which to engage with recent debate concerning the uptake in sound studies of the philosophy of Gilles Deleuze. In so doing we will attempt to develop a path between conflicting sides of sound studies, putting forward an understanding of sound that presents it not as an uninterrogated ontological essence, nor as only a term in a discursive web, but as a problem which must be repeatedly posed anew. We will consider points where this may yet be pushed towards a reified, essentialized understanding of the nature of sound, but move to offset this by emphasizing the production of a practical process of learning and experimentation.

\section{Deleuzian sound studies}

Despite its increasing institutional status and recognition as a distinct disciplinary field, we still often find works in sound studies attempting to reformulate the very terrain of their

\footnotetext{
${ }^{1}$ Cage, Silence, 8.

${ }^{2}$ Cage, A Year from Monday, 31. This notion is drawn from the thought of Ananda Coomarawamy, which Cage encountered at some point in the mid-1940s. See also Silence, 100, 155, 173, 194, and elsewhere.

${ }^{3}$ Cage, Silence, 10.
} 
enquiry from the beginning. The most fundamental question remains radically open - what is the status of sound in sound studies? In recent years Deleuze's philosophy has had a key role to play in providing answers to this question. Through theorists such as Christoph Cox, Steve Goodman and Greg Hainge, ${ }^{4}$ Deleuze's thought has been most commonly used to combat perceived inadequacies in the prevalent methodologies of sound studies, including those derived from cultural studies. These approaches, we are told, are still operating within the terms of the 'linguistic turn' in the humanities, and as such are not fit for the object of sound. Critical models designed for enquiries into visual and textual objects are said to fail to capture that which is distinctive about sound. ${ }^{5}$

Arguing that approaching sound in this manner is unavoidably anthropocentric and insular, resurgent realist, materialist and naturalist theories have sought to overcome the limits of representation and signification that characterize cultural studies models. In so doing they have attempted to more adequately capture the nature of sound, prior to its cultural or subjective mediation. ${ }^{6}$ It is here that the thought of Deleuze has been most important. In particular his theory of affect, drawing from Spinoza and especially as elaborated upon in the influential interpretation of Brian Massumi, ${ }^{7}$ has provided the grounding for a sonic realism which attempts to articulate sound as vibratory matter or force, not immediately reducible to its subjective or cultural interpretation. ${ }^{8}$

Recently, however, these approaches have been subject to critique. Most prominent has been that of Brian Kane. Describing the 'ontological turn' that is made with these Deleuzian approaches, Kane argues that in positioning research into 'universals concerning the nature of sound, the body, and media' over and above 'auditory culture', understood as research into the cultural, social, technological and political constitution of sound and listening, ${ }^{9}$ an unnecessarily strong distinction is made by the 'Deleuzian' scholars. This distinction diminishes their ability to determine the role played by culturally-situated practices and techniques in constituting sound, and their other ontological givens, as objects of enquiry. ${ }^{10}$

With particular reference to the theories of Cox and Hainge, Kane develops a critique of this ontological position by drawing on the analytic philosophers Nelson Goodman and W.V.O. Quine. Kane notes that for both Cox and Hainge, the sonic arts play a crucial role in disclosing the essential nature of sound. In Cox's case this is as material flux, ${ }^{11}$ for Hainge as boundlessly creative noise. ${ }^{12}$ Both are associated with Deleuze's notion of the virtual, understood as the realm of fundamental difference that lies beneath the fixity and identity of the empirical actual. ${ }^{13}$ As Kane describes the relation between art and sound for these thinkers, the work of art acts as a disclosure of its ontological condition, i.e. the condition of sound or noise. ${ }^{14}$ But following Goodman and Quine, this notion of disclosure does not match the kind of critical enquiry that ontology entails. Ontology, Kane follows Quine in arguing,

\footnotetext{
${ }^{4}$ See for example Cox, "Beyond Representation and Signification," Goodman, Sonic Warfare, or Hainge, Noise Matters.

${ }^{5}$ See Goodman, Sonic Warfare, 9-10, or Cox, "Beyond Representation and Signification," 146.

${ }^{6}$ Ibid, 148.

${ }^{7}$ Massumi, Parables of the Virtual.

${ }^{8}$ For a close evaluation of the 'sonic affect', see Scrimshaw, "Non-cochlear sound."

${ }^{9}$ Kane, "Sound studies without auditory culture," 3

${ }^{10}$ Ibid., 16

${ }^{11}$ Ibid., 9.

12 Ibid., 10 .

${ }^{13}$ Ibid., 4.

14 Ibid., 11.
} 
asks the question 'what is there?' 15 The ontological question cannot allow for degrees of reality, which for the 'Deleuzian' approach to sound would be in the argument that the virtual is in some respects more 'real' than the actual.

Drawing then from Nelson Goodman, Kane argues that the mistake that Cox and Hainge have made is in confusing embodiment with exemplification. Embodiment is an ontological matter - it concerns whether or not an object $i$ s of a certain kind. One can claim that a given sound is a sound, but not that one sound is more of a sound than another sound.

Exemplification, on the contrary, is a form of reference. ${ }^{16}$ We can perfectly well state that one work of art can better exemplify sonicity than another, better draw our attention to its sonicity. But to exemplify sonicity would not be to enter into a privileged ontological realm beyond representation and signification. On the contrary, acts of exemplification are acts of reference - what is being exemplified would always be a given understanding of sonicity, already constituted within a representational structure. ${ }^{17}$ The ultimate claim here is that Cox's sound or Hainge's noise cannot be understood as ontologically essential - these terms, like their exemplifications in works of art, are culturally mediated, historically situated, and operating within a system of signification.

My goal in this essay is not so much to defend these specific uses of Deleuze's thought in sound studies from Kane's criticisms, nor is it to offer a Deleuzian 'corrective' to these 'improperly' Deleuzian theories. ${ }^{18}$ I will rather seek to outline how reading Deleuze from another perspective could help us reconsider the status of a 'Deleuzian sound studies'. This may ultimately be taken in the direction of reassessing these existing theories and uncovering a richness and depth to them that Kane's generalized reading does not allow for, or it may urge us to consider new ways of approaching sound studies through Deleuze.

Neither is my goal to refute or repudiate Kane's arguments, which are powerful and deserve to be taken into consideration at the offset of any enquiry into sound. But it will be useful to bear some aspects of Kane's position in mind. One aspect concerns the status of ontology. From an early stage in his writings Deleuze is concerned with ontology, and particularly the distinctive form it had taken in contemporary philosophy. This concern is indicated in 'The Method of Dramatization', for instance, where we find Deleuze asking whether the traditional ontological question we have seen through Quine, of 'what is this?', as a question of identification and subsequently of the demarcation of identities into a referential system, ${ }^{19}$ may bias the enquiry to the exclusion of other questions, such as 'who? how? how much? where and when? in which case?' ${ }^{20}$

This reframing of the stakes of ontology takes place in the context of what Deleuze calls ontology's 'contemporary renaissance', a renaissance based on 'the question-problem complex'. ${ }^{21}$ With this Deleuze refers to the mid-twentieth century French epistemology and philosophy of mathematics and science that produced its own distinctive solutions to the theoretical problems that Quine answered with his famous argument for a spartan nominalism

\footnotetext{
15 Ibid., 12; and Quine, "On What There Is."

${ }^{16}$ Kane, "Sound studies without auditory culture," 11-12.

${ }^{17}$ Ibid., 13.

18 Though I believe that in some respects this could prove fruitful - I would argue, for example, that Deleuzian sound studies has tended to install a normative hierarchy in the actual-virtual relation which is not present, or is at the very least complicated, in Deleuze's own thought.

${ }^{19}$ On this topic the discussion of logic in Deleuze and Guattari, What is Philosophy?, chapter 6, is crucial.

${ }^{20}$ Deleuze, "The Method of Dramatization," 96.

${ }^{21}$ Deleuze, Difference and Repetition, 195-96.
} 
with minimal ontological commitments. Any thorough engagement with Deleuze's 'ontology' must contend with this context. ${ }^{22}$

This is not our only point of connection to Kane's remarks. We can put alongside Deleuze's upheaval of the traditional questions of ontology the response that John Cage offers to Nelson Goodman's critique of his work. Discussing Cage's indeterminate graphical notational schemes, specifically that of section BB of Concert for Piano and Orchestra, Solo for Piano, Goodman argues that that the lack of semantic and syntactic detail at the level of the score may lead us to performances which have no evident character of unity as a work, no clear point of resemblance conjoining them to the notational form. ${ }^{23} \mathrm{With}$ inadequate differentiation at the level of the score we are left, says Goodman, with no basis for evaluating a performance as a 'true copy' of the piece, and as such this method of scoring does not qualify as notational.

It is important to note that Goodman's conditions for notation are exceedingly stringent, and differ from his conditions for exemplification. ${ }^{24}$ And indeed, the philosopher Noël Carroll argues that Cage's work succeeds at the level of Goodman's understanding of exemplification - that the non-musical sounds in performances of Cage's compositions act as exemplifications of everyday noise, insofar as they are framed in a musical context. ${ }^{25}$ This anticipates Kane's claim that Cox or Hainge could perfectly well say a given artwork may exemplify (a given understanding of) sound or noise, but that a category mistake has occurred when it is said to embody it.

Goodman could have softened his position on Cage's notation, but he does not. For Goodman there can be no determinate relation between Cage's graphic score and its performance. This, however, is not something that Cage objects to as such. Take Cage's initially elusive but evocative remark in response to Goodman's criticisms, that 'writing is one thing, performing another, and listening a third; and that there is no reason for these three operations to be linked'. ${ }^{26}$ The precise sense of this statement is at first glance unclear, but what we can see is that Cage is not satisfied to maintain the referential bond that has traditionally held between performance and notation, nor the further bond to reception.

It is not merely that Cage's graphically notated works fail to achieve the status of notated works, it is that Cage does not deem this an appropriate measure for them to be judged on.

\footnotetext{
${ }^{22}$ A full enquiry into the stakes of these competing positions with regards to the philosophy of mathematics and its relation to philosophical and theoretical practice more generally is beyond the scope of this essay, but it would no doubt be an interesting line to pursue with regards to both our understanding of Deleuze in relation to sound studies, and to the existing field of 'Deleuzian' literature in sound studies. This line of enquiry could illuminate and deepen our understanding of the sound studies that has drawn from Deleuze, or it could reveal a critical limit. Insofar as 'Deleuzian sound studies' has generally interpreted Deleuze in terms of a neo-

Nietzschean ontology of forces and a neo-Bergsonian distinction between the virtual and the actual, we may ask whether there has been due consideration to how these Nietzschean and Bergsonian concerns are reformulated through the intellectual climate of Deleuze's emergence into philosophical maturity. Of this intellectual milieu it is perhaps only the work of Gilbert Simondon, doubtlessly of central importance to Deleuze, that has been addressed in significant depth in the field of sound studies. For work situating Deleuze in this context, see Eyers, Post-Rationalism, and Peden, Spinoza Contra Phenomenology.

${ }^{23}$ Goodman, Languages of Art, 188.

${ }^{24}$ See for instance his famous claim "the most miserable performance without actual mistakes does count as [a genuine instance of a work], while the most brilliant performance with a single wrong note does not" (Ibid., 186).

${ }^{25}$ Carroll, "Cage and Philosophy," 95.

${ }^{26}$ Cage, For the Birds, 129.
} 
Whether it is appropriate or not to speak of performances of Cage's works in terms of exemplification is also put in doubt - if the elements of music are to be considered as separate operations, can the purpose of a performance really be to point towards the unifying characteristic of everyday noise? The question is, then, if these elements of musical practice are not to be 'linked', then what is the relation between them to be?

\section{Deleuze, Cage, and sound-space}

We have introduced two related deviations from Kane's critical model. Through Deleuze, an approach to ontology derived not from a Quinean nominalism but from question-problem complexes. And, through Cage, a tentative rejection of the notion that referential relations between identifiable terms have full explanatory purchase on our understanding of our objects of enquiry. It is around this that we will develop an approach to sound.

We can begin by elaborating on a point where Deleuze and Cage come together in a manner which appears most resonant with the use of Deleuze in 'Deleuzian' sound studies, namely the reference in Deleuze \& Guattari's A Thousand Plateaus to Cage's notion of sound-space. Deleuze \& Guattari begin by drawing on a musical example to discuss what they term the plane of immanence and the plane of transcendence. The latter of these is posed in terms of Western art music and the theory of harmony, described as 'a transcendent compositional principle that is not of the nature of sound, that is not "audible" by itself or for itself". ${ }^{27}$ Musical composition has relied on a principle beyond the sounds themselves, on a structure the structure of harmony - which, while not necessarily present within the sounds or their audition, comes to define them. Harmony comes to determine the kinds of relations that take place between sounds, with only an abstracted reference to any notion of the sounds themselves.

With the plane of immanence, on the contrary, we no longer turn to form to characterize that which exists. There are rather 'only relations of movement and rest, speed and slowness between unformed elements', ${ }^{28}$ where activity takes place without reference to principles exceeding the activity itself. It is with this plane that the twentieth-century musics rejecting the dominance of harmony have contended, and have attempted to articulate themselves through. And for Deleuze \& Guattari it is Cage who 'first and most perfectly' deploys the fixed plane of sound that will mark the musical plane of immanence, fixed not as immobile but as 'the absolute state of movement as well as of rest, from which all relative speeds and slownesses spring'. ${ }^{29}$

The path towards the 'Deleuzian' strand of sound studies is visible here. Sound is understood in its own terms, in its material reality, prior to the transcendent imposition of external structuring principles. We have on one hand the transcendence of formal organizational schemas such as harmony, on the other the immanence of an ontology of sound. Deleuze \& Guattari's terminology here will not yet be clear, and indeed it may appear to have the character of the unjustified ontological assertions Kane claims of Deleuzian sound studies. In order to develop a clearer picture of our position, and to begin to differentiate it from the previously described 'Deleuzian sound studies', we will now look more closely at the basis of 'sound-space'.

\footnotetext{
${ }^{27}$ Deleuze and Guattari, A Thousand Plateaus, 266.

${ }^{28} \mathrm{Ibid}$

${ }^{29}$ Ibid., 267.
} 
Cage's distinctive understanding of sound is indicated as early as his late-1930s essay 'Future of Music: Credo', in which he focuses on the idea that the modern composer is no longer limited to the traditional orchestral instrumental model, and can through the use of technological advances produce 'new sound experiences'. ${ }^{30}$ The music of the future, says Cage, is an 'all-sound' music, where any division between musical sound and non-musical sound is dissolved and the composer deals with the entire field of sound. This idea is gradually given a greater formal and practical status, ultimately in terms of what he calls sound-space. In Cage's formulation of this space in the mid-1950s, which he would make use of largely unchanged for the rest of his life, any given sound is determined by five distinct but inseparable variables - frequency, amplitude, timbre, duration and morphology. ${ }^{31}$

In a musical practice where the understanding of sound is derived from this sound-space, dealing with sound is no longer a matter of adhering to a gradated schema of predetermined pitch relations, but rather of extracting distinct sounds from the entire field of potential sounds. In this understanding, unlike with the always-already-given rules of harmony, when dealing with sound-space individual sounds must be produced. It is not enough to know the variables that make up a sound, as the sound does not pre-exist its sounding. Why is this? To understand, we must elaborate on this notion of the production of sounds.

In making these moves with regards to musical tradition, Cage was part of a strand of artistic modernism which received notable theoretical attention going into the 1960s. In Difference and Repetition Deleuze terms the characteristic works produced in this movement 'problematic' works, decentered works which adhere to a logic other than that of identification and representation, be these in the form of fictional narrative, artistic figuration or musical tonality. This depiction immediately jars with the referential logic Nelson Goodman uses to engage with Cage's work. Particularly useful for understanding this point of contention, and more generally the conceptual stakes of this moment that takes place between the vanguard of artistic practice and this particularly active moment in French philosophy, is Deleuze's concept of the problematic Idea.

Deleuze's use of the term 'problematic' is derived in its first instance from Kant. ${ }^{32}$ In the Critique of Pure Reason Kant discusses what he calls the 'hypothetical' use of reason with regards to regulative concepts ${ }^{33}$ - when it is used 'problematically'. This realm concerns universals which are not certain or given, which are not knowable as objects as such, but are nevertheless assumed, as Ideas, and are tested to determine their universality.

While for Deleuze Kant too quickly settles on three such universals - God, World and Self this notion remains useful to him insofar as, unlike the application of the concept elsewhere in Kant's critical project, there is not the immediate assumption of an isomorphism between knowledge and its object. For Deleuze it is a traditional cornerstone of transcendental philosophy that 'the conditions of the real object of knowledge must be the same as the

\footnotetext{
${ }^{30}$ Cage, Silence, 5.

${ }^{31}$ Ibid., 9.

${ }^{32}$ Our discussion here contrasts with that of Christoph Cox, who seeks to evacuate all that is Kantian from Deleuze, insofar as Cox's understanding of sound contains no remainder of the subject-object split. See Cox, "Beyond Representation and Signification," 153.

${ }^{33}$ Kant, Critique of Pure Reason, A646f/B674f.
} 
conditions of knowledge' ${ }^{34}$ It is of the nature of the concepts of understanding that all objects of experience will conform to them.

This understanding of experience points to the crux of Deleuze's critique of and remobilization of Kant, namely that for Deleuze Kant's understanding of experience is 'divided into two irreducible domains'. ${ }^{35}$ We find in the Critique of Pure Reason a theory of the sensible which pertains to the real only insofar as it conforms with the possible experience of the subject, and in the Critique of the Power of Judgement a theory of the beautiful which 'deals with the reality of the real'. ${ }^{36}$ Deleuze's concern is to understand how we can invert the Kantian formulation of the conditions of possible experience grounded in the transcendental subject - and here we will be reminded of some features of the 'ontological turn' - and understand the conditions of 'real' experience.

Here Deleuze draws from Salomon Maimon, a contemporary of Kant and one of his earliest critics. Maimon finds in Kant a failure to prove the fact of possible experience, arguing that Kant rather presupposes necessary and lawlike connections. ${ }^{37}$ Maimon's great contribution, argues Deleuze, is to take what Kant posits as given and attempt to understand it in terms of its genesis. ${ }^{38}$ For Deleuze the orderliness of conceptual experience cannot be assumed, we must discover how it came to be, how it was produced. This consideration allows for the possibility that it is not simply the case that objects of understanding are wholly conditioned by the structures of possible experience, but that something of the real may interrupt, that these objects may in some sense reciprocally constitute experience. It is for this reason that Deleuze turns to the problematic - where the problem is no longer a knowable object, but rather concerns the movement of a regulative process, the inexhaustible exploration of an Idea.

Deleuze's procedure for taking this Kantian notion of the regulative Idea into his own problematic Idea passes through, most notably, Leibniz, Bergson and Maimon. This formulation is one of the key aspects developed across Difference and Repetition and as such cannot be engaged in detail here, but in short: from Maimon Deleuze takes the notion that differential relations are the most basic, genetic elements of sensation. This is drawn together with the Leibnizian petites perceptions. Leibniz speaks of 'the confused murmur coming from the innumerable set of breaking waves heard by those who approach the seashore', ${ }^{39}$ which, as Deleuze interprets it, unbinds the traditional logic of clear and distinct versus obscure and confused. Instead we find an apperception of the whole that is clear and confused, insofar as it finds itself incapable of grasping the fundamental elements that make up the sound, or distinct and obscure, insofar as the petites perceptions themselves are grasped, as differential relations or singularities, but their cohesion into the whole of the sound has not yet been established.

Through this argument for the differential basis of sensibility and understanding, Deleuze claims that it is in the 'reciprocal synthesis of differential relations' that we find 'the substance of Ideas'. ${ }^{40}$ As such Deleuze pushes Kantian transcendental philosophy through

\footnotetext{
${ }^{34}$ Deleuze, The Logic of Sense, 105.

${ }^{35}$ Deleuze, Difference and Repetition, 68.

${ }^{36}$ Ibid.

${ }^{37}$ Maimon, Essay on Transcendental Philosophy, 100.

${ }^{38}$ Deleuze, Difference and Repetition, 173.

${ }^{39}$ Leibniz, "Discourse on Metaphysics," $\$ 33$.

${ }^{40}$ Deleuze, Difference and Repetition, 173.
} 
Maimon in order to confer an objective status onto the hypothetical vagueness of the Kantian problematic Idea, yet without rendering it as a wholly knowable object. The final aspect, then, is a Bergsonian split between the actual and the virtual. This virtual sounds somewhat different than the appearance of undifferentiated flux sometimes suggested in Cox's account - in this understanding the Idea is made up of differential elements in reciprocal relation, ${ }^{41}$ and is completely determined, differentiated, and structured at the level of the virtual. However, it is not yet actualized into distinguished parts, differenciated. At the level of its virtual differentiation it remains 'enveloped and in need of interpretation', ${ }^{42}$ that is to say, it remains a problem awaiting a solution. ${ }^{43}$

The use of differential calculus here points us towards a re-articulation of the problems Kane raised regarding ontology. Anticipating Deleuze \& Guattari's extensive and more explicit comments on logic and analytic philosophy in What is Philosophy?, the use of the 'so-called barbaric or pre-scientific ${ }^{44}$ calculus resists the set theoretical axiomatization that serves as a key reference point for much of analytic philosophy's method. This is not to deny the importance of such axiomatization, but rather to value a degree of irreducibility at the level of the problematic. ${ }^{45}$

The distinction between the Deleuzian problematic Idea, and likewise Deleuze \& Guattari's later reframing of the term 'concept', and the Kantian concepts of understanding, could in this respect equally be said of, for example, Frege's notion of the concept. The Fregean concept is understood in terms of what objects may fall under it, ${ }^{46}$ a formulation which is extended through Quine's claim that 'to be is to be the value of a variable'. ${ }^{47}$ Significant here is that this definition comes while Quine is stating that this cannot be the grounds for adjudicating between rival ontologies. The Deleuzian problematic Idea, on the contrary, is precisely a process of selection which is obscured by the propositional understanding of the concept. ${ }^{48}$ For Deleuze

representation and knowledge are modelled entirely upon propositions of consciousness which designate cases of solution, but those propositions themselves give a completely inaccurate notion of the instance which engenders them as cases, and which they resolve or conclude. ${ }^{49}$

'The instance which engenders' is the problematic Idea, understood not as a conceptual subsumption, but, in attempting to maintain the dynamism and process of the differential relations which ground it, as a complex process of comprehending problems, composing them well, and producing solutions to them - as a process of learning. ${ }^{50}$

\footnotetext{
${ }^{41}$ Ibid., 203.

42 Ibid., 24.

43 Ibid., 209.

${ }^{44}$ Ibid., 170

${ }^{45}$ See Smith, "Mathematics and the Theory of Multiplicities," and for a broader contextualization, Bell, Deleuze and Guattari's What is Philosophy?.

${ }^{46}$ Frege, "On Concept and Object."

47 Quine, "On What There Is," 202.

${ }^{48}$ Deleuze, Difference and Repetition, 162.

${ }^{49}$ Ibid., 192.

${ }^{50}$ Ibid., 192.
} 
The relation to Cage's conception of sound-space is rendered clearly in Deleuze's example of such a problematic Idea, the Idea of colour. ${ }^{51}$ It is not, argues Deleuze in an early text on Bergson, that different colours are objects under the concept 'colour', but rather that different colours are 'nuances or degrees of the concept itself'. ${ }^{52}$ There is not an abstract idea of colour under which individual colours can be categorized, but it is rather that the Idea of colour is the real, concrete condition for individual colours. We see this when light passes through a lens and converges on a single point: 'what we have then is 'pure white light,' the very light that "makes the differences come out between the shades." The Idea of colour provides the genetic element of all colours, with individual colours being said to 'solve' the 'problem' posed by the problematic Idea of colour. ${ }^{53}$

We can follow this with the Idea of sound, which Deleuze says is 'like white noise' ${ }^{54}$ Cage's sound-space can be understood as a problematic field, defined by, in Deleuze's terms, 'the interdependence of the variable coefficients ${ }^{55}$ - frequency, amplitude, timbre, duration and morphology, reciprocally determined and held together in a differential relationship. This can be translated into artistic production. Just as the field of colour is a problematic field through which a careful, practiced engagement can produce the yellows of van Gogh, the blues of Matisse or the whites of Rauschenberg, so too does the composer or musician take on the problematic field of sound and produce sounds. In each case it is crucial that 'sound' is not a pre-given identity, as it would be in the case of the everyday noises that Noël Carroll claims Cage's work exemplifies. The problematic Idea of sound is rather created through a critical procedure with regards to the conceptual givens of music - we see in Cage's work this move through harmony, the timbral standards of orchestral instruments, the spatial organization of sound that the orchestra hall provides... - and the selection and composition of new elements into a new model of production. At every stage it is crucial the problematic Idea is not an essence defined in abstraction from everyday practices, but is rather seen as a process of learning, creation and experimentation.

\section{Points of resistance and indeterminacy}

However, there remains an aspect of the problematic Idea, and sound as problematic Idea, that sits uneasily with both Cage's and Deleuze's respective trajectories. The conceptual basis of this is the status of the problematic Idea as structure. Tracing the problematic Idea across Deleuze's texts of this period, particularly The Logic of Sense, we see how the concept of the problematic Idea is to be understood through Deleuze's own articulation of the project of theoretical structuralism, and the problematic Idea takes, in Difference and Repetition, the place of structure. The Idea is, as we have seen, completely determined at the level of the virtual, this providing its productive capacity - it is only insofar as its relations are wholly internal, as an enclosed structure of reciprocally determined elements held together in a differential relationship, that it maintains the objectivity adequate to the problem.

A concern about structure is prefigured in Deleuze's thought even before Difference and Repetition and The Logic of Sense, in the closing pages of the 1967 text 'How Do We

\footnotetext{
${ }^{51}$ Ibid., 206.

52 Deleuze, "Bergson's Conception of Difference," 43.

${ }^{53}$ Ibid.

${ }^{54}$ Deleuze, Difference and Repetition, 206.

${ }^{55}$ Ibid., 46. Cage himself drew on the work of Bergson. For a detailed and nuanced reading of the Bergson-

Cage-Deleuze conjunction, see Joseph, Experimentations, 133-172
} 
Recognize Structuralism?'. Here Deleuze expresses the still-open question about how structuralism can accommodate a genuine form of practice, ${ }^{56}$ a sentiment echoed in the second half of the The Logic of Sense, where Deleuze bemoans the 'ridiculousness of the thinker ${ }^{57}$ who contends only with the surface play of structural relations. This concern is given new conceptual clarity in Félix Guattari's 'Machine and Structure', a response to Deleuze's The Logic of Sense which sparked a lifelong collaboration between the two. In this essay Guattari takes on the still-structuralist element of Deleuze's thought to that point and insists that the productive function Deleuze finds in structure can in fact only be understood to be of the order of Guattari's concept of the machine. ${ }^{58}$ This is a point which Deleuze readily accepts, as we see in the use of that concept in Anti-Oedipus and A Thousand Plateaus.

We see this prominently in the 'Memories of a Bergsonian' section of the tenth plateau of $A$ Thousand Plateaus. What we find here is an implicit confrontation with Deleuze's own structuralism, taking place through the concept of becoming. The logic of becoming concerns itself with 'irreducible dynamisms drawing lines of flight' ${ }^{59}$ precedence here being ascribed to the 'block of becoming' rather than the terms it passes through. In this respect the logic of actualization that describes the productive action of the structural problematic Idea remains too much within the realm of fixed terms, a production too determined by its initial structural conditions, diminishing, as Deleuze \& Guattari see it, the dynamism and mobility of real becoming. With structural thought the precise character of the change that takes place between the terms is lost.

There is much to be said about this passage from Deleuze to Deleuze-Guattari, but what we will focus on here is what it implies for sound-space - speaking not only of its positive sense as a mobile and dynamic problematic Idea, but also addressing how its generality as a compositional structure appears also to produce some difficulties and tensions in Cage's practice. We will address this by considering the passage that Cage's work takes into the 1960s, particularly in terms of how his ideas and practices are interpreted and recontextualized.

From the late 1930s Cage utilized various techniques, from the use of early electronic equipment to the manipulation of instruments such as with the prepared piano, in order to open up the field of music to sounds it had previously disallowed. One aspect of this was an attempt to leave behind the weight of the history of classical music and its associated judgements of taste, and at the turn of the 1950s, coinciding with his anechoic chamber visit, this was given a kind of formal order through the introduction of chance into his compositional process. With chance not only do harmony and the other standards of the Western art music tradition no longer hold authority over what sounds are to be used in a piece, but neither do the choices of the composer.

In this period chance applied only at the level of composition. In the late 1950s, however, Cage became dissatisfied with how, while chance composition 'identifies the composer with no matter what eventuality', ${ }^{60}$ the performer nevertheless had to identify him- or herself with the score, with the work identified as an object. Here we are reminded of Cage's notion that

\footnotetext{
${ }^{56}$ Deleuze, "How Do We Recognize Structuralism?" 191.

${ }^{57}$ Deleuze, The Logic of Sense, 157.

${ }^{58}$ Guattari, "Machine and Structure," 111.

${ }^{59}$ Deleuze and Guattari, A Thousand Plateaus, 237.

${ }^{60}$ Cage, Silence, 36
} 
there was no necessary connection between composing, performing and listening, that in some respect they each have an autonomous function - an autonomy which is diminished when the performance has the ultimate reference point of the score. This led Cage to the development of performative indeterminacy, the procedure by which elements of chance are installed at the level of the performance itself. ${ }^{61}$ Cage's own primary method for introducing this indeterminacy was through graphical scoring methods, as we previously discussed in relation to Nelson Goodman's criticisms. Given the understanding of sound-space we have developed, we can now quickly respond to these criticisms - to say that the score is not to be thought of in a directly notational relation to performance, that it itself is a 'problematic' figure which the performer must engage with, re-problematize, 'learn' from in performing. We will return to this, but of more immediate interest is a curious outcome of this development of indeterminacy.

It is first of all crucial to note that Cage did not develop the notion of performative indeterminacy alone. In the summer of 1958 Cage held a class on Experimental Composition at the New School for Social Research. Cage's class description termed it a 'course in musical composition with technical, musicological, and philosophical aspects', based not on conventional musical studies of pitch but rather the other parameters of sound-space. ${ }^{62}$ Among its participants were Allan Kaprow, Dick Higgins, George Brecht, Jackson Mac Low and Al Hansen, artists who were responsible for developing a series of 'theatrical' artistic models from the late 1950s onwards, particularly through Kaprow's 'happenings' and the activities of the Fluxus group. Cage would later state that it was during his time teaching at the New School that he found himself 'shifting from object to process', ${ }^{63}$ and while nascent forms of compositional and performative indeterminacy are present in his key texts and pieces of the early 1950s, at this juncture its movement appears to accelerate and reach a more refined understanding. Performative indeterminacy appears to be produced through a collaborative effort between Cage and his students. ${ }^{64}$

For Cage performative indeterminacy and the use of graphical scoring, in particular the flexible transparency sheets derived from sections of the Concert for Piano and Orchestra, Solo for Piano and used for his first three Variations pieces and elsewhere, allowed for each performance to '[depart] from music' and to reframe the sound field anew - 'the universe within which the action is to take place is not preconceived'. ${ }^{65}$ But beyond Cage's own compositional practice, it is the radical departure from music his Experimental Composition students and their peers made that marks the most profound result of performative indeterminacy, still resonating through artistic practices today.

We see this in the text scores associated with the Fluxus group, where sound moves towards a pluralized understanding, no longer reducible to its sound-space definition. La Monte Young's work marks this passage elegantly, with Composition 1960 \#10 refining the method of \#7's two notes 'to be held for a long time' with the simple instruction 'Draw a straight line and follow it' ${ }^{66}$ Implications of sound persist, but there is no necessity of a sonic outcome. Likewise Yoko Ono's work binds together varied understandings of sound and silence banal and absurd, possible and impossible, inseparable from social context. 'Take a tape of

\footnotetext{
${ }^{61}$ Ibid., 28.

${ }^{62}$ See Altshuler, "The Cage Class."

${ }^{63}$ Fetterman, John Cage's Theatre Pieces, 233.

${ }^{64}$ See Kim, "The Formalization of Indeterminacy."

${ }^{65}$ Cage, Silence, 28.

${ }^{66}$ Young, An Anthology of Chance Operations.
} 
the sound of snow falling. / This should be done in the evening. / Do not listen to the tape. / Cut it and use it as strings to tie gifts with. / Make a gift wrapper, if you wish, using the same process with a phonosheet. ${ }^{97}$

This provides a striking instance of how a problematic Idea, in this case sound, is not a fixed concept under which objects are gathered, but is a process of selection, learning, practice. In engaging with the problem of sound, the students of Cage's Experimental Composition class posed it anew. A more direct example in relation to Cage comes via pianist and composer David Tudor. For his performances of Cage's Variations II Tudor developed a system for interpreting the piece, converting the measurements of the original score into a looser and more open-ended performative model ${ }^{68}$ - in the terms we have laid out here, a problematic rather than solely notational engagement with the score. Furthermore, Tudor associated the piece intrinsically with his ongoing investigations into musical technology, by binding its performance to his development of the amplified piano. Here the engagement with the score is a transformative act, where the performer has his or her own hand in the constitution of the problem - as James Pritchett notes, it would 'not be out of the question' to call Variations II Tudor's first composition. ${ }^{69}$

Our reading of Cage and the mutable problematic Idea of sound is complicated, however, by instances in which Cage was not so generous to other performers who sought to reframe his work. A telling example is that of Charlotte Moorman. Moorman's prolonged series of performances for cello of Cage's 26' 1.1499' for a String Player - a piece written to be strenuously difficult, tending towards performative impossibility - would incorporate increasing elements of performance. One such recitation took place with Nam June Paik in which Paik, stripped to the waist, took the place of the cello, his back being bowed by Moorman. Of this performance Cage would later speak of the 'striking thing' of 'tak[ing] a piece of mine and playing it in a way that didn't have to do with the piece itself', and in private correspondence describing 26'1.1499' as '[t] he one Charlotte Moorman has been murdering all along, ${ }^{70}$

Marking Moorman's performances is a direct confrontation with cultural and social questions in a way Cage would tend to avoid in his compositions. There is both a connection to the emerging practices of feminist performance art and the significance of the prominently displayed partially naked Asian male body at the height of the Vietnam War. Leaving aside the directly political questions regarding Cage's objections, Moorman, it seems quite clear, started from an attempt to 'authentically' interpret Cage's extraordinarily difficult and significantly open piece. Only gradually, over a great many performances, did she revise her approach to the piece to produce something quite different - a close engagement with the work indicated by her heavily annotated notation. ${ }^{71}$ While this produced something unrecognisable, this kind of rejection of iterability from one performance to another is likewise built into many of Cage's indeterminate pieces, and seems a key characteristic of the problematic musical work.

\footnotetext{
${ }^{67}$ Ono, Grapefruit.

${ }^{68}$ See Panzner, The Process That Is the World, 155.

${ }^{69}$ Pritchett, "David Tudor as Composer/Performer."

${ }^{70}$ Quoted in Piekut, Experimentalism Otherwise, 149-150.

${ }^{71}$ Ibid., 158.
} 
We find in a text by Cage on Nam June Paik that the core of his objection to Moorman is found in the 'liberties taken [...] in favor of actions rather than sound events in time'. ${ }^{72}$ Here the sound-space arises again, and in apparent tension with the openness, mutability and connectability associated with post-Cagean art. Cage seems unwilling to account for the possibility that Moorman had taken on the work anew, as an experimental recasting of the problem itself in a close practical engagement with the piece, through which the problem mutated from a largely sonic problem into a problem of another order. Deleuze remarks in Difference and Repetition that we remain slaves 'so long as we do not possess a right to the problems, to a participation in and management of the problems', ${ }^{73}$ but here in the understanding of the completely determined problematic Idea, as the field of sound-space, there appear to persist points of blockage and tension between the problem and its experimental production. We are left to ask, then, if the problematic Idea, as a regulative, Kantian Idea, is still implicated in an interpretive schema in opposition to an experimental practice. Is sound again reified for Cage? Do we again find ourselves open to Brian Kane's criticisms, of a musical practice grounded on unjustified assertions regarding the essential nature of sound?

Here we ask again the question that is raised in the final pages of 'How Do We Recognize Structuralism?' and that echoes through Deleuze's work - how are we to account for, to enact, the mutation of structure, the transition from one structure to another, or from one problem to another? What kind of procedure have the problems of music and sound, has the problem of music as sound, undergone in the shift in Cage's practice we have outlined, and how does it guide us through these contradictory points of closure - and through the unsatisfying elements, the points of inefficiency, we find with Deleuze's structuralism, particularly with regards to the problematic Idea?

While we have seen some indication of possible points of closure and fixity that remain in the otherwise extraordinarily mobile and mutable theoretical apparatus of A Thousand Plateaus, there is nevertheless something surprising in Deleuze \& Guattari's final collaborative text, What is Philosophy?, regarding the divisions that are reinstated, particularly between the operations of philosophy, science and art. Likewise, a step back towards a problematic framework seems to take place. Here a resistance towards positing the philosophical concept as a given, or as pre-formed, leads Deleuze \& Guattari to argue that the concept is selfpositing, that it has 'an autopoietic characteristic by which it is recognized' ${ }^{74}$ We find, then, a closure of the concept comparable to the determination of the problematic Idea in Difference and Repetition, and perhaps moreso. Here philosophical creation is staged in solely philosophical terms.

As Keith Ansell-Pearson notes, a difficulty arises here in articulating a feedback process between the pedagogy of the concept and the pedagogy of historical experience. ${ }^{75}$ The reciprocal processes that were key to the departure from Kant appear in some respects devalued. Something notable here is that What is Philosophy? was written differently than were Deleuze \& Guattari's other collaborative works, the weight of its production more heavily on Deleuze. ${ }^{76}$ While Guattari's voice cannot be extracted, there are aspects where this distinction is significant. The question of autopoiesis is one such aspect. The inclusion of this

\footnotetext{
72 Cage, "On the Work of Nam June Paik," 21.

${ }^{73}$ Deleuze, Difference and Repetition, 158.

${ }^{74}$ Ibid., 11.

75 Ansell-Pearson, Germinal Life, 204.

${ }^{76}$ Dosse, Gilles Deleuze \& Félix Guattari, 14-15.
} 
notion appears to be on Guattari's suggestion, but in his own concurrent work, Chaosmosis, it appears in a subtly different manner. For Guattari the autopoietic character of the machine is inseparable from its relation to other machines - it 'always depends on exterior elements in order to be able to exist as such'. ${ }^{77}$ Autopoiesis commonly understood in its biological conception defines its 'auto' in opposition to an allopoietic notion of constitution by external inputs by rendering it an exclusively biological concept, distinct from, for example, 'social systems, technical machines, crystalline systems' ${ }^{78}$ For Guattari this is inadequate, and comparable to the structuralist dominance of the linguistic signifier. His own machinic autopoiesis, on the contrary, 'maintain[s] diverse types of relations of alterity', ${ }^{79}$ not as 'external' constitutive forces, but as constitutively inseparable from other assemblages at a machinic level.

Thinking in terms of this notion of autopoiesis rather than that of What is Philosophy? may allow us to think more readily of the reciprocity between an embedded, historical practice and the constitution of concepts; of the problematic Idea of sound as something malleable, open to mutation through experimental practices. But we should not be too quick to do so. It is not enough to simply accept the 'blockage' in Deleuze's thought as a contingent point to be overcome through an extended notion of autopoiesis. Rather, it is crucial that we understand this in terms of the extraordinarily stringent conditions for creation which are present in Difference and Repetition and which Deleuze reinvests in a different context in his final works. The late essay 'Postscript on Control Societies' is crucial in understanding this move. Here Deleuze raises the concern that with a transition from disciplinary society to control society we see a logic of modulation co-opted into the operations of the state, ${ }^{80}$ in terms that sound almost like a self-critique directed towards the Deleuze \& Guattari of $A$ Thousand Plateaus. It is on this basis that the line between creation rightly speaking and the discourse of 'creativity' we find in the 'disciplines of communication" 81 - of enterprise, marketing, 'ideas men', but also paralleled in a later critique of conceptual art, towards which Guattari seemed more sympathetic than Deleuze - cannot be easily drawn, and is perhaps why Deleuze returns to such a seemingly foreclosed model regarding the legitimation of creation. $^{82}$

For Cage, via Deleuze, the Idea of sound is not a fixed determination. It is a process of learning. But at every step in this procedure it must be addressed critically and carefully. 'You don't do it with a sledgehammer, you use a very fine file'. ${ }^{83}$ For both Deleuze and Cage it is crucial to resist a turn to an uncontrolled relativism, as this will always only reinforce the status quo. This is also why it remains crucial to ask fundamental ontological questions of sensation, or affect, but to ask them problematically - without these questions we remain prisoners of the given, of what is rather than what can become. Though we can certainly reject the positions Cage and Deleuze take, the barriers we come across in engaging with sound through their work need not be indicative of failings in their approach. On the contrary, they indicate the intrinsic difficulties of taking on the problem of sound - not as a question of knowledge, but as an inexhaustible practice of learning and experimentation.

\footnotetext{
77 Guattari, Chaosmosis, 37.

${ }^{78}$ Ibid., 39.

${ }^{79}$ Ibid., 40.

${ }^{80}$ Deleuze, "Postscript on Control Societies," 178.

${ }^{81}$ Deleuze and Guattari, What is Philosophy?, 10.

${ }^{82}$ See Toscano, "In Praise of Negativism."

${ }^{83}$ Deleuze and Guattari, A Thousand Plateaus, 160.
} 


\section{Bibliography}

Altshuler, Bruce. “The Cage Class.” In FluxAttitudes, edited by Cornelia Lauf and Susan Hapgood, 17-23. Gent: Imschoot, 1991.

Ansell-Pearson, Keith. Germinal Life: The Difference and Repetition of Deleuze. London: Routledge, 1999.

Bell, Jeffrey A. Deleuze and Guattari's What is Philosophy?: A Critical Introduction and Guide. Edinburgh: Edinburgh University Press, 2016.

Cage, John. A Year from Monday: New Lectures and Writings. Middletown, CT: Wesleyan University Press, 1968.

Cage, John. For the Birds: In Conversation with Daniel Charles. London: Marion Boyars, 1976.

Cage, John. "On the Work of Nam June Paik." In Nam June Paik: Video Time, Video Space, edited by Toni Stooss and Thomas Kellein, 21-26. New York: Harry Abrams, 1993.

Cage, John. Silence: Lectures and Writings. Middletown, CT: Wesleyan University Press, 1961.

Carroll, Noël. "Cage and Philosophy." Journal of Aesthetics and Art Criticism 52, no. 1 (1994): 93-98.

Cox, Christoph. "Beyond Representation and Signification: Toward a Sonic Materialism." Journal of Visual Culture 10, no. 2 (2011): 145-161.

Deleuze, Gilles. “Bergson's Conception of Difference." Chap. 5 in Desert Islands and Other Texts 1953-1974. Edited by David Lapoujade. Translated by Michael Taormina. Los Angeles: Semiotext(e), 2004.

Deleuze, Gilles. Difference and Repetition. Translated by Paul Patton. London: Continuum, 1994.

Deleuze, Gilles. "How Do We Recognize Structuralism?" Chap. 22 in Desert Islands and Other Texts 1953-1974. Edited by David Lapoujade. Translated by Michael Taormina. Los Angeles: Semiotext(e), 2004.

Deleuze, Gilles. The Logic of Sense. Translated by Mark Lester with Charles Stivale. New York: Columbia University Press, 1990.

Deleuze, Gilles. "The Method of Dramatization." Chap. 14 in Desert Islands and Other Texts 1953-1974. Edited by David Lapoujade. Translated by Michael Taormina. Los Angeles:

Semiotext(e), 2004. 
Deleuze, Gilles. "Postscript on Control Societies." Chap. 17 in Negotiations: 1972-1990, Translated by Martin Joughin. New York: Columbia University Press, 1995.

Deleuze, Gilles and Félix Guattari. A Thousand Plateaus: Capitalism and Schizophrenia. Translated by Brian Massumi. Minneapolis: University of Minnesota Press, 1987.

Deleuze, Gilles and Félix Guattari, What is Philosophy?. Translated by Hugh Tomlinson and Graham Burchell. New York: Columbia University Press, 1994.

Dosse, François. Gilles Deleuze \& Félix Guattari: Intersecting Lives. Translated by Deborah Glassman. New York: Columbia University Press, 2010.

Eyers, Tom. Post-Rationalism: Psychoanalysis, Epistemology, and Marxism in Post-War France. London: Bloomsbury, 2013.

Fetterman, William. John Cage's Theatre Pieces: Notations and Performances. Amsterdam: Harwood Academic Publishers, 1996.

Frege, Gottlob. “On Concept and Object.” Mind, New Series 60, no. 238 (Apr., 1951): 168180.

Goodman, Nelson. Languages of Art: An Approach to a Theory of Symbols. Indianapolis: Bobbs-Merrill, 1968.

Goodman, Steve. Sonic Warfare: Sound, Affect and the Ecology of Fear. Cambridge, MA: MIT Press, 2010.

Guattari, Félix. "Machine and Structure." Chap. 10 in Molecular Revolution: Psychiatry and Politics. Translated by Rosemary Sheed. New York: Penguin, 1984.

Guattari, Félix, Chaosmosis: An Ethico-Aesthetic Paradigm. Translated by Paul Bains and Julian Pefanis. Indianapolis: Indiana University Press, 1995.

Hainge, Greg. Noise Matters: Towards an Ontology of Noise. London: Bloomsbury, 2013.

Joseph, Branden W. Experimentations: John Cage in Music, Art, and Architecture. New York: Bloomsbury, 2016.

Kane, Brian. "Sound studies without auditory culture: a critique of the ontological turn." Sound Studies 1, no. 1 (2015): 2-21. DOI: 10.1080/20551940.2015.1079063

Kant, Immanuel. Critique of Pure Reason. Translated by Paul Guyer and Allen W. Wood. Cambridge: Cambridge University Press, 1998.

Kim, Rebecca Y. "The Formalization of Indeterminacy in 1958." In John Cage: October Files 12, edited by Julia Robinson, 141-170. Cambridge, MA: MIT Press, 2011. 
Leibniz, Gottfried Wilhelm. "Discourse on Metaphysics." Chap. 13 in Philosophical Essays. Translated by Roger Ariew and Daniel Garber. Indianapolis: Hackett, 1989.

Maimon, Salomon. Essay on Transcendental Philosophy. Translated by Nick Midgley, Henry Somers-Hall, Alistair Welchman and Merten Reglitz. London: Continuum, 2010.

Massumi, Brian. Parables of the Virtual: Movement, Affect, Sensation. Durham, NC: Duke University Press, 2002.

Ono, Yoko. Grapefruit: A Book of Instructions and Drawings by Yoko Ono. New York: Simon \& Schuster, 1970.

Panzner, Joe. The Process That Is the World: Cage/Deleuze/Events/Performances. New York: Bloomsbury, 2015.

Peden, Knox. Spinoza Contra Phenomenology: French Rationalism from Cavaillès to Deleuze. Stanford: 2014.

Piekut, Benjamin. Experimentalism Otherwise: The New York Avant-Garde and Its Limits. Berkeley: University of California Press, 2011.

Pritchett, James "David Tudor as Composer/Performer in Cage's Variations II." Paper presented at The Art of David Tudor, Getty Research Institute, 2001. Accessed 23/03/2017 https://www.getty.edu/research/exhibitions_events/events/david_tudor_symposium/pdf/pritch ett.pdf

Quine, Willard V. "On What There Is." In Semantics and the Philosophy of Language, edited by Leonard Linsky, 189-207. Urbana: University of Illinois Press, 1952.

Scrimshaw, Will. "Non-cochlear sound: on affect and exteriority." In Sound, Music, Affect: Theorizing Sonic Experience, edited by Marie Thompson and Ian Biddle, 27-43. New York: Bloomsbury, 2013.

Smith, Daniel. "Mathematics and the Theory of Multiplicities: Deleuze and Badiou Revisited." Chap. 17 in Essays on Deleuze. Edinburgh: Edinburgh University Press, 2012.

Toscano, Alberto. "In Praise of Negativism." In Deleuze, Guattari and the Production of the New, edited by Simon O'Sullivan and Stephen Zepke, 56-67. London: Continuum, 2008.

Young, La Monte, ed. An Anthology of Chance Operations. New York: La Monte Young \& Jackson Mac Low, 1963. 